\title{
ANC-BNC Titrations and Geochemical Modeling for Characterizing Calcareous and Siliceous Mining Waste
}

\author{
Clémentine Drapeau ${ }^{1}$, Cécile Delolme ${ }^{2}$, Clément Vézin ${ }^{3}$, Denise Blanc ${ }^{4}$, Thomas Baumgartl ${ }^{5} \mathbb{D}$, Mansour Edraki $^{6} \mathbb{D}$ \\ and Laurent Lassabatere $3, *$ (D)
}

1 Direction Régionale de L'environnement, de L'aménagement et du Logement (DREAL), Auvergne Rhône-Alpes, Unité Départementale du Rhône, 63 Avenue Roger Salengro, 69100 Villeurbanne, France; clementine.drapeau@developpement-durable.gouv.fr

2 ENTPE, 3 rue Maurice Audin, F-69518 Vaulx-en-Velin, France; cecile.delolme@entpe.fr

3 Université de Lyon, UMR5023 Ecologie des Hydrosystèmes Naturels et Anthropisés, Université Lyon 1, ENTPE, CNRS, 3 rue Maurice Audin, F-69518 Vaulx-en-Velin, France; clement.vezin@gmail.com

4 Université de Lyon, INSA-Lyon, Déchets Eau Environnement Pollutions (DEEP), 7 rue de la Physique, F-69621 Villeurbanne, France; denise.blanc@insa-lyon.fr

5 Geotechnical and Hydrogeological Engineering Research Group (GHERG), Federation University Australia, Churchill, VIC 3841, Australia; t.baumgartl@federation.edu.au

6 Centre for Mined Land Rehabilitation, Sustainable Minerals Institute (SMI), The University of Queensland, St Lucia, QLD 4072, Australia; m.edraki@cmlr.uq.edu.au

* Correspondence: laurent.lassabatere@entpe.fr

Citation: Drapeau, C.; Delolme, C.; Vézin, C.; Blanc, D.; Baumgartl, T.; Edraki, M.; Lassabatere, L. ANC-BNC Titrations and Geochemical Modeling for Characterizing Calcareous and Siliceous Mining Waste. Minerals 2021, 11, 257. https://doi.org/ $10.3390 / \min 11030257$

Academic Editor: Juan Antelo

Received: 24 January 2021

Accepted: 23 February 2021

Published: 28 February 2021

Publisher's Note: MDPI stays neutral with regard to jurisdictional claims in published maps and institutional affiliations.

Copyright: (c) 2021 by the authors Licensee MDPI, Basel, Switzerland. This article is an open access article distributed under the terms and conditions of the Creative Commons Attribution (CC BY) license (https:// creativecommons.org/licenses/by/ $4.0 /)$.
Abstract: Pyrite and calcite are mineral phases that play a major role in acid and neutral mine drainage processes. However, the prediction of acid mine drainage (AMD) or contaminated neutral drainage (CND) requires knowledge of the mineral composition of mining waste and the related potential for element release. This paper studies the combination of acid-base neutralizing capacity (ANC-BNC) with geochemical modeling for the characterization of mining waste and prediction of AMD and CND. The proposed approach is validated with three synthetic mineral assemblages: (1) siliceous sand with pyrite only, representing mining waste responsible for AMD, (2) siliceous sand with calcite and pyrite, representing calcareous waste responsible for CND, and (3) siliceous sand with calcite only, simulating calcareous matrices without any pyrite. The geochemical modeling approach using PHREEQC software was used to model $\mathrm{pH}$ evolution and main element release as a function of the added amount of acid or base over the entire $\mathrm{pH}$ range: $1<\mathrm{pH}<13$. For calcareous matrices (sand with calcite), the results are typical of a carbonated environment, the geochemistry of which is well known. For matrices containing pyrite, the results identify different $\mathrm{pH}$ values favoring the dissolution of pyrite: $\mathrm{pH}=2$ in a pyrite-only environment and $\mathrm{pH}=6$ where pyrite coexists with calcite. The neutral conditions can be explained by the buffering capacity of calcite, which allows iron oxyhydroxide precipitation. Major element release is then related to the dissolution and precipitation of the mineral assemblages. The geochemical modeling allows the prediction of element speciation in the solid and liquid phases. Our findings clearly prove the potential of combined ANC-BNC experiments along with geochemical modeling for the characterization of mining waste and the assessment of risk of AMD and CND.

Keywords: pyrite; calcite; $\mathrm{pH}$; speciation; geochemical modeling

\section{Introduction}

Mining and mineral processing activities produce large volumes of byproducts known as mining waste. The impacts of tailing ponds and waste rock piles can potentially lead to serious environmental, health, socioeconomic, and geotechnical issues [1-6]. Responsible mining activities demand sustainable management of mineral mine waste. The primary objective is to reduce waste production, followed by recycling and reusing waste as much as possible [7]. Remediation is considered as the last resort for managing the impacts 
of mining waste. In any case, it is necessary to understand and predict the geochemical processes underlying elemental release (major and trace) from mining waste. Pyrite and calcite are mineral phases that play a major role in two mine drainage processes: acid mine drainage (AMD) [8,9] and contaminated neutral drainage (CND) [10-12]. According to the literature, pyrite dissolution is catalyzed by ferric oxidation acidifying the solution, also described as the AMD process. Contaminated neutral drainage can occur when sulfide oxidation is weak or when neutralization is strong enough $[13,14]$. In most investigations of closed mines, high concentrations of trace metals and sulfates were mobilized by leaching from tailings $[15,16]$. Under these conditions, effluents are generated and some toxic metals and metalloids, such as $\mathrm{Ni}, \mathrm{Zn}, \mathrm{Co}, \mathrm{As}$, and $\mathrm{Sb}$, may be solubilized $[1,10]$. In both drainage situations (AMD or CND), pyrite and other mineral phase dissolutions pose a crucial environmental problem [17]. Pyrite is the most common sulfur-containing mineral phase. It can contain many trace elements ( $\mathrm{Ag}, \mathrm{Au}$, Te (tellurium), $\mathrm{Tl}$ (thallium), $\mathrm{Zn}$, etc.), at times in significant concentrations (e.g., up to $10 \%$ for arsenic) [18].

There are many studies that addressed major and trace element release during AMD processes, but most relied on bulk measures of those processes and very few investigated element release over the whole $\mathrm{pH}$ range [19-21]. Many papers are based on an experimental characterization of mining waste without including a detailed identification of mineral and pollutant-bearing phases. Some presented the role of the carbonate phase on leachate $\mathrm{pH}$ near $6[1,10]$. Some highlighted the impact of the carbonate phase on geochemical mechanisms of pyrite dissolution, particularly the precipitation of iron oxyhydroxides [22-24]. However, speciation of soluble major and trace elements is rarely characterized. Most studies focused on the kinetics and total release of trace elements $[1,9,17,25]$. It is argued that the carbonate phase is not sufficient to limit the release of elements, even if it buffers the acidity produced by the dissolution of pyrite $[1,10]$. Thus, there is some uncertainty regarding its classification, management, and reuse in contrast to AMD [8]. It is important to identify this aspect even more precisely, to characterize the mineral assemblages, and to predict element speciation in order to fully understand the potential elements released and involved in geochemical mechanisms during AMD and CND processes.

In addition to the approaches mentioned above, acid-base neutralizing capacity (ANC-BNC) titration tests have proven to be accurate and interesting tools for the characterization of buffer capacity and element release of solid matrices [26]. ANC-BNC involves placing the studied matrix in contact with an acidic or alkaline solution in a closed reactor during a $24-48 \mathrm{~h}$ period. Then, $\mathrm{pH}$ and element release are monitored and reported as a function of the amount of acidity or alkalinity. Such experiments were used to assess element release from several types of cement and concrete matrices $[20,27]$ into contaminated soils [28], including even natural soils [29]. Several protocols were developed for these titration experiments [30], but the main principles remain the same. Recently, the European Council proposed a standardize protocol that is considered as a benchmark (European standard NF EN 14429) [31].

Coupled with geochemical modeling, ANC-BNC titrations provide a quite efficient tool for characterizing solid matrices in terms of mineral assemblages and element speciation [20,27]. Geochemical modeling has several benefits in the identification of minerals compared with other techniques. It allows the identification of geochemical processes and mechanisms, particularly through access to all geochemical information for each model step iteration (e.g., element speciation, physicochemical parameters, and solid phase quantity). These numerical data supplement the intensive experimental work and avoid labor-intensive and cumbersome experimental procedures such as sequential extraction (SSE). SSE, which is known to be expensive and time-consuming, partitions elements into exchangeable, reducible, oxidizable, residual, carbonate organic matter fractions that are not necessarily representative of the real element speciation in the solid phase [32,33].

To the authors' knowledge, the use of ANC-BNC titrations along with geochemical modeling to characterize mining waste and element release has not been investigated in depth, particularly the capability of such titration experiments to identify the right 
mineral composition of mining waste and element speciation in the solid and liquid phases. Our study used the ANC-BNC approach (titrations and geochemical modeling) to characterize buffer capacity and major element release from contrasting mining wastes, including waste with high or very low carbonate content and pyrite. We relate buffer capacity and element release to the mineral assemblage composing the studied matrices and the dissolution-precipitation processes. In order to avoid side mechanisms and uncontrolled composition of mineral phases, we used mineral assemblages made of pure phases (standardized sand, pure calcite, and pyrite) instead of real matrices. The use of mineral assemblages appears to be an efficient way to remove uncertainty related to the complexity of real matrices and allows perfect knowledge of tested solid matrices. To carry out ANC-BNC experiments, we used the European standard NF EN 14429 [31]. The geochemical model was implemented in PHREEQC to precisely model the experimental protocol (added amounts and volumes, vessel used, etc.) to predict solid and liquid phase compositions as a function of the amount of acid or alkalinity added. Several compositions in terms of minerals and amounts were tested until a good fit of the observed $\mathrm{pH}$ and element release was obtained. The optimum composition of the predicted mineral assemblage was compared to the synthetic matrices, and then the modeled data were discussed with regard to the element speciation in the liquid and solid phases as a function of $\mathrm{pH}$. Our findings produce an adequate model that correctly represents the experimental element release and buffer capacity and provides relevant insight into the interplay of pyrite and calcite in element release.

\section{Materials and Methods}

\subsection{Acid and Base Neutralization Capacity (ANC-BNC)}

Acid and base neutralizing capacity tests characterize the physicochemical stability and buffer capacity of a solid phase when it is placed in contact with a source of acidity or alkalinity. ANC-BNC titrations were conducted according to the European standard NF EN 14429 [31], developed by the European Committee for Standardization (Comité Européen de Normalisation, CEN). This protocol proved to be efficient for different types of matrices $[20,23,26]$. The experimental protocol was divided into four steps: (1) prestudy, with simple titration to estimate the amount of acid and base to be introduced to cover the whole range of $\mathrm{pH},(2)$ batch preparation using a solid/liquid ratio of around $1 / 10$, (3) mechanical stirring for $48 \mathrm{~h}$, and (4) measurement and determination of element concentration after filtration at $0.45 \mu \mathrm{m}$.

Calcite (calcium carbonate; Sigma-Aldrich, Ultrapure, Merck) and pyrite (iron disulfide; Aldrich, Ultrapure, Merck) solid phases were chosen for the ANC-BNC titrations. Extra-pure sea sand (siliceous sand), $\mathrm{SiO}_{2}$ (Fisher Chemical), was chosen as the background solid phase. Three types of mineral assemblages were tested as follows: (1) calcite in siliceous sand, (2) pyrite in siliceous sand, and (3) calcite-pyrite assemblage in siliceous sand. The compositions of the three synthetic mixtures were fixed as follows: (1) $3 \mathrm{~g}$ of calcite and $7 \mathrm{~g}$ of $\mathrm{SiO}_{2}$, (2) $0.1 \mathrm{~g}$ of pyrite and $9.9 \mathrm{~g}$ of $\mathrm{SiO}_{2}$, and (3) $3 \mathrm{~g}$ of calcite, $0.1 \mathrm{~g}$ of pyrite, and $6.9 \mathrm{~g} \mathrm{SiO}_{2}$. The solids were sieved at $1 \mathrm{~mm}$. The three mineral assemblages were referred to as calcite $/ \mathrm{SiO}_{2}$, pyrite $/ \mathrm{SiO}_{2}$, and calcite/pyrite $/ \mathrm{SiO}_{2}$. Mixtures 2 and 3 represent common types of mining waste responsible for AMD and CND, respectively [1,23]. Mixture 1 was added to complete the experimental plan and determine the role of calcite.

These solid matrices $(10 \mathrm{~g})$ were put in contact with $100 \mathrm{~mL}$ of solution in vessels with a volume of $250 \mathrm{~mL}$. Acid and base were added by means of $\mathrm{HNO}_{3}$ and $\mathrm{NaOH}$ solutions at $5 \mathrm{~mol} / \mathrm{L}$. The volumes of distilled water and $\mathrm{HNO}_{3}$ or $\mathrm{NaOH}$ solution were determined to maintain the same liquid volume, i.e., $100 \mathrm{~mL}$. The quantity of acid or base added was adapted to the shape of the curves, with more points in the vicinity of the buffering zone. To this point, the pre-study phase provided a clear idea of the zones to refine. The closed reactors were agitated with a specific device at $7 \mathrm{rpm}$. These had to be opened from time to time to allow leakage of $\mathrm{CO}_{2}$ and reduce the risk of over-pressurization. At the beginning and the end, the closed reactors were opened for leachate measurement at $t=0$, 
44, and $48 \mathrm{~h}$. Leachate measurements included the following physicochemical parameters: $\mathrm{pH}$ (Fisher Scientific), conductivity (sensION+, Hach), and oxidation-reduction potential (Intellical MTC101, Hach). At the end, solutions were filtered through a $0.45 \mu \mathrm{m}$ filter and split into three subsamples: one to determine total concentrations (calcium, iron, and sulfur), one to measure cations $\left(\mathrm{Ca}^{2+}, \mathrm{Fe}^{2+}\right)$, and one to measure anions $\left(\mathrm{SO}_{4}{ }^{2-}\right)$. The first subsamples were analyzed for total calcium and iron using flame atomic adsorption (AA) spectrometry (PinAAcle 900T, Perkin Elmer) and for total sulfur using inductively coupled plasma-optical emission spectrometry (ICP-OES; ULTIMA 2). The second subsamples were acidified using $\mathrm{HNO}_{3}(5 \mathrm{~mol} / \mathrm{L})$ when too alkaline (i.e., $\mathrm{pH}<7$ ) before being analyzed by ion chromatography (Dionex ICS 1100). The third subsamples were directly analyzed for $\mathrm{SO}_{4}{ }^{2-}$ using ion chromatography (Dionex ICS 900).

To characterize the buffer capacity and element release, the $\mathrm{pH}$ variation was plotted as a function of the amount of acid and base added as follows: $\mathrm{pH}=\mathrm{f}\left(\mathrm{Eq} \mathrm{H}^{+}\right)$, where $\mathrm{Eq}$ $\mathrm{H}^{+}$is the amount of $\mathrm{H}^{+}$ions added and is a negative value when $\mathrm{OH}^{-}$is added. To ease the comparison between $\mathrm{pH}$ and the redox potential (pe), $\mathrm{pH}$ was plotted as pe. Lastly, element concentration was plotted as a function of $\mathrm{pH}$.

\subsection{Geochemical Modeling}

The geochemical modeling was implemented using PHREEQC software (interactive version alpha 3.1.2.8538, United States Geological Survey). This makes it possible to conceptually represent the experiments. PHREEQC, on the basis of a deterministic approach, proposes a thermodynamic model. All chemical reactions and related equations are resolved by the software's numerical tools [34]. The llnl reference database (Lawrence Livermore National Laboratory) was used, as it enrolls many mineral phases. The geochemical modeling was used to fit the ANC-BNC titrations and, thus, test several hypotheses on the geochemical processes and element release and speciation [35]. Several scenarios were tested regarding the amounts of mineral phases submitted to ANC-BNC titrations and the phases expected to form following the dissolution of the original mineral assemblages.

The modeling methodology was inspired from previous studies on urban stormwater sediments [19-21]. There were three steps: (1) estimate the mineral assemblage (minerals and amounts) initially present that can precipitate or dissolve (literature review study and inverse modeling) [36], (2) directly model the complete ANC-BNC titration experiments (adding all acid/base amounts in the modeled closed reactors), and (3) compare observed and modeled $\mathrm{pH}$ and element concentrations in the liquid phase and analyze the predicted mineral assemblage. These three steps were repeated for several initial mineral assemblages until the modeled data got close to the observations. Once the optimum scenario was identified, the predicted element speciation in the liquid and solid phases was plotted as a function of $\mathrm{pH}$ and considered as indicative of the real speciation. In this study, only the final optimal model is presented, although it resulted from a large number of runs $\left(\sim 100\right.$ models for calcite $/ \mathrm{SiO}_{2}$ and pyrite $/ \mathrm{SiO}_{2}$ alone and 200 models for calcite/pyrite $/ \mathrm{SiO}_{2}$ ). The thermodynamic constants implemented in the llnl database were never changed; only the initial mineral assemblage and the list of phases allowed to form or dissolve were optimized.

The final model was defined by the solid and gaseous phase and their initial contents (mineral assemblage for the solid phase), the amount of base or acid added to the system, and the list of phases that were not initially in the mixture but were expected to form and potentially dissolve, defining transitional states (from a thermodynamic point of view). For the gaseous phase, as the batches were opened during the experiment to avoid overpressurization and the risk of explosion, the batch reactors were considered as partially opened. The gaseous phase was modeled with a constant volume and very low partial $\mathrm{CO}_{2}$ pressure to mimic $\mathrm{CO}_{2}$ leakage during the opening of the batch reactors. The phases that were allowed to precipitate included gypsum, foshagite [37], and iron hydroxides $\left(\mathrm{Fe}(\mathrm{OH})_{2}, \mathrm{Fe}(\mathrm{OH})_{3}\right)[38]$. 


\section{Results and Discussion}

\subsection{Physicochemical Parameters}

Figure 1a illustrates the difference in the buffer capacity between the three types of matrices. Indeed, the $\mathrm{pH}$ curve for the pyrite $/ \mathrm{SiO}_{2}$ matrix shows very low buffering capacity (approximately $\mathrm{pH}=2$ ). Buffering capacity is revealed by the stabilization of $\mathrm{pH}$, despite the addition of acid or base. In contrast, $\mathrm{pH}$ curves for calcite $/ \mathrm{SiO}_{2}$ and calcite/pyrite/ $\mathrm{SiO}_{2}$ reveal an important buffer zone between $0.05 \mathrm{~mol} \mathrm{H}^{+}$and $0.55 \mathrm{~mol} \mathrm{H}^{+}$ added, corresponding to $\mathrm{pH} \approx 6$. This can be directly explained by the buffer capacity of calcite (see also the discussion on modeling below).

a) $\mathrm{pH}=\mathrm{f}(\mathrm{Eq} \mathrm{H}+$ added $)$

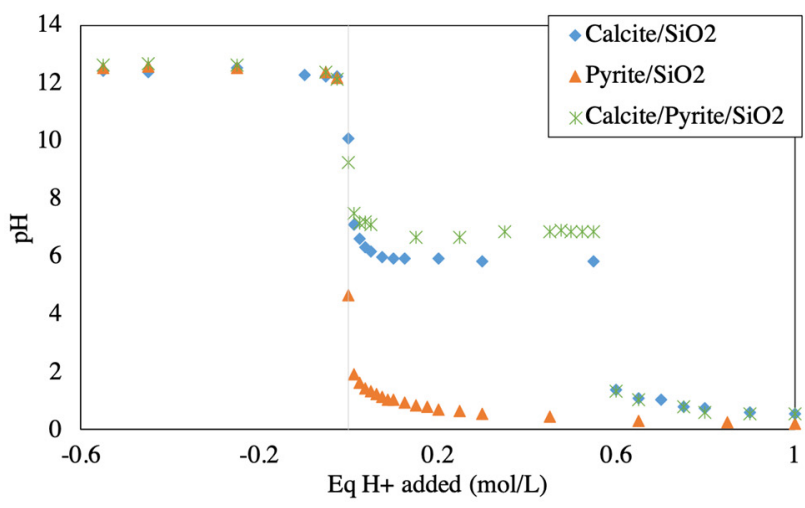

b) $\mathrm{pH}=\mathrm{f}($ redox potential)

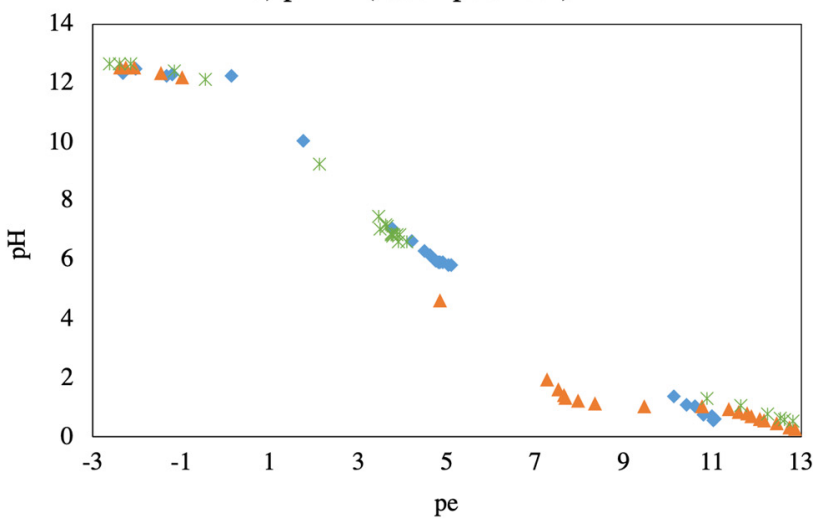

Figure 1. $\mathrm{pH}(\mathbf{a})$ and redox potential (b) of three synthetic matrices: calcite $/ \mathrm{SiO}$, pyrite $/ \mathrm{SiO}_{2}$, and calcite $/ \mathrm{pyrite} / \mathrm{SiO}$. The vertical line indicates the point of equilibrium with pure water (in Figure 1a).

The variation in redox potential as a function of $\mathrm{pH}$ was similar among the three matrices in terms of both extreme values and slopes (Figure 1b). However, the decrease in redox potential with $\mathrm{pH}$ was more important for pyrite $/ \mathrm{SiO}_{2}(\mathrm{pH} \approx 2$ and $\mathrm{pe} \approx 7-9$; Figure $1 b$ ), which is characteristic of pyrite oxidation. In addition, the decrease in redox potential was less marked in the presence of calcite, showing its effect in reducing the effect of pyrite dissolution on the redox potential. Indeed, according to the literature, the dissolution of pyrite impacts the redox potential, but to a lesser extent in the presence of calcite $[39,40]$.

The $\mathrm{pH}$ variations between $\mathrm{t}=44$ and $48 \mathrm{~h}$ were low with regard to the precision of the $\mathrm{pH}$ meter for all mixtures (data not shown here): $0.17 \mathrm{pH}$ units for calcite $/ \mathrm{SiO}_{2}$ only, $0.08 \mathrm{pH}$ units for pyrite $/ \mathrm{SiO}_{2}$, and $0.24 \mathrm{pH}$ units for calcite/pyrite $/ \mathrm{SiO}_{2}$. Consequently, we considered that short-term thermodynamic equilibrium was reached, which justified the use of the PHREEQC geochemical model based on chemical equilibrium. However, Table 1 presents the percent of maximum element release, highlighting that pyrite dissolution was not complete. This finding is consistent with the literature; pyrite dissolution kinetics are very slow (suspension equilibrium time is $300 \mathrm{~h}$ ) [41], which means that only a fraction of pyrite dissolved over the course of the experiment. Such a result indicates the difference between short- and long-term chemical stabilization (or equilibrium). To account for this, the initial amounts of pyrite allowed to react in the batch reactors were reduced in the geochemical model. Limiting the initial amount was the chosen way to introduce the kinetic limitation of pyrite dissolution and distinguish between short- and long-term equilibrium.

Table 1. Contents of release elements in solution as a function of mixture and $\mathrm{pH}$ area $(\mathrm{mol} / \mathrm{mol})$.

\begin{tabular}{ccccccc}
\hline & \multicolumn{2}{c}{ Calcium Release } & \multicolumn{2}{c}{ Iron Release } & \multicolumn{2}{c}{ Sulfur Release } \\
\hline Matrix & Calcite $/ \mathrm{SiO}_{2}$ & Calcite $/$ pyrite $/ \mathrm{SiO}_{2}$ & $\mathrm{Pyrite} / \mathrm{SiO}$ & Calcite/pyrite $/ \mathrm{SiO}_{2}$ & $\mathrm{Pyrite} / \mathrm{SiO}$ & $\mathrm{Calcite} / \mathrm{pyrite} / \mathrm{SiO}{ }_{2}$ \\
\hline Acid area & $97 \%$ & $99 \%$ & $45 \%$ & $25 \%$ & $52 \%$ & $37 \%$ \\
Basic area & $<1 \%$ & $<1 \%$ & $<1 \%$ & $<1 \%$ & $6 \%$ & $11 \%$ \\
\hline
\end{tabular}




\subsection{Modeling of Mineral Phase Dissolution}

First, the proposed inversion (based on iterating steps 1-3 of the geochemical modeling approach, as described in Section 2) proved quite efficient to retrieve the initial composition of the synthetic matrices. The method pointed out the right minerals quite quickly, and the amounts of involved minerals were close to the targeted amounts. We should note that we had to reduce the quantity of mineral assemblages in contact with water, probably in relation to the kinetic limitations, as explained above. Figure 2 shows the experimental data along with the modeled data of $\mathrm{pH}$ and redox potential for the three synthetic matrices. The ANC/BNC titrations were well represented with the initial conditions and chemical reactions selected in the final geochemical model.

a) $\mathrm{pH}=\mathrm{f}(\mathrm{Eq} \mathrm{H}+$ added $)$

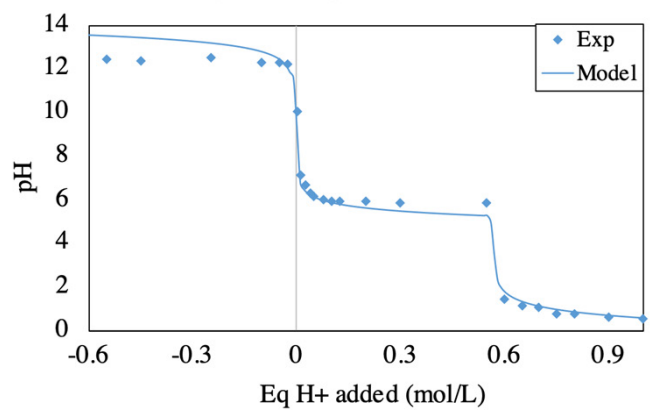

c) $\mathrm{pH}=\mathrm{f}(\mathrm{Eq} \mathrm{H}+$ added $)$

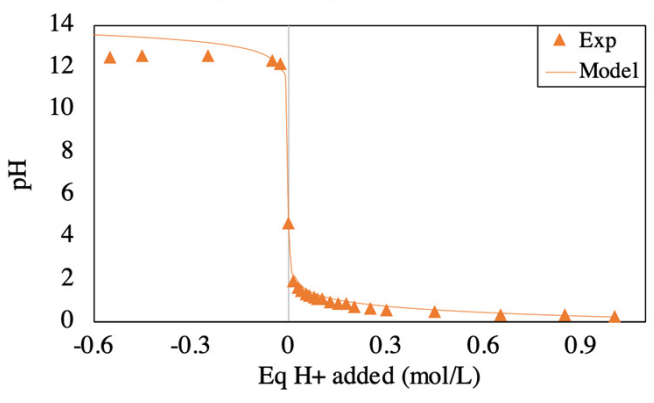

e) $\mathrm{pH}=\mathrm{f}(\mathrm{Eq} \mathrm{H}+$ added $)$

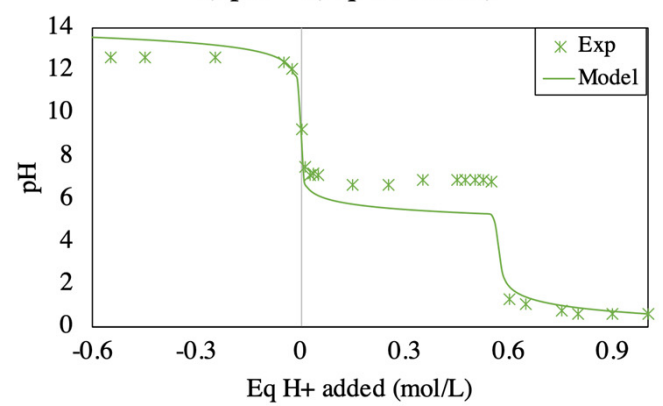

b) $\mathrm{pH}=\mathrm{f}($ redox potential $)$

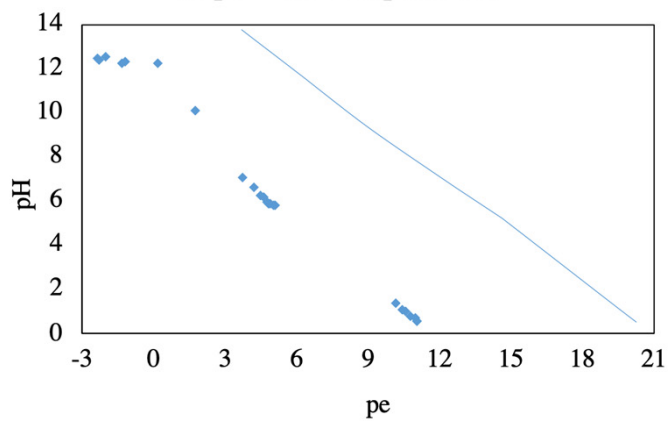

d) Redox potential $=\mathrm{f}(\mathrm{pH})$

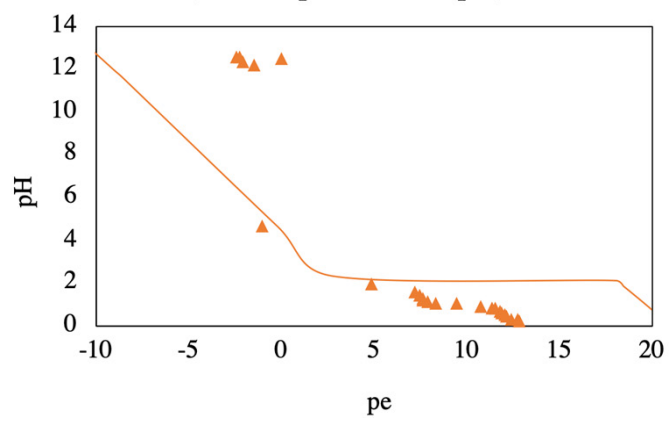

f) $\mathrm{pH}=\mathrm{f}($ redox potential)

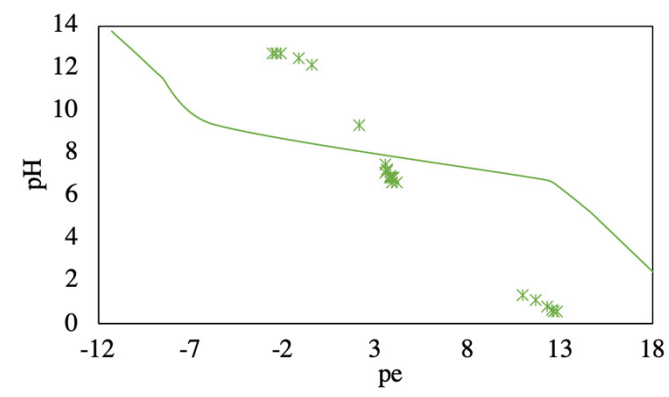

Figure 2. $\mathrm{pH}$ as a function of $\mathrm{H}^{+}$equivalents added for (a) calcite $/ \mathrm{SiO}_{2}$, (c) pyrite $/ \mathrm{SiO}_{2}$, and (e) calcite/pyrite $/ \mathrm{SiO}_{2}$ assemblages, and relationship between redox potential (pe) and $\mathrm{pH}$ for (b) calcite $/ \mathrm{SiO}_{2}$, (d) pyrite $/ \mathrm{SiO}_{2}$, and (f) calcite/pyrite $/ \mathrm{SiO}_{2}$. The vertical line in (b) indicates the point of equilibrium with pure water.

The $\mathrm{pH}$ curve of calcite only has three distinct areas (Figure 2a): (i) basic, (ii) buffer, and (iii) acidic. In the basic area, the curve reaches an asymptote at approximately $\mathrm{pH}=12$, which indicates the presence of quartz and shows the contribution of the $\mathrm{SiO}_{2}$ in the calcite $/ \mathrm{SiO}_{2}$ assemblage. The total duration of the experiment $(48 \mathrm{~h})$ was sufficient to initiate quartz dissolution [42]. The same trend was observed for the three synthetic matrices. The 
$\mathrm{pH}$ buffer zone was situated at approximately $\mathrm{pH}=6$ (Figure 2a), which is the buffer capacity of calcite for open systems $[43,44]$. The dissolution of calcite consumes protons. This $\mathrm{pH}$ range is important because it represents the range of natural waters [45]. In the acidic area, the calcite was completely dissolved. After $0.55 \mathrm{~mol} / \mathrm{L}$ of acid was added, the $\mathrm{pH}$ curve decreased sharply until it reached the asymptote at approximately $\mathrm{pH}=1$.

The redox potential of the calcite $/ \mathrm{SiO}_{2}$ matrix decreased linearly when the $\mathrm{pH}$ increased (Figure 2b). According to the literature and theory, these parameters are interdependent: an increase in $\mathrm{pH}$ is accompanied by a decrease in redox potential (pe). This linearity is related to the low redox reactivity of calcite [46]. The modeling was satisfactory with an accurate simulation of trends, despite the observed difference between observations and simulation (Figure $2 b$, line versus points). The offset between the model and observed data is expected to be related to the pyrite dissolution process (see below). In addition, we guess that the perturbation of the closed reactors (open during titrations to avoid over-pressurization) may have added an additional source of errors.

For pyrite $/ \mathrm{SiO}_{2}$, the $\mathrm{pH}$ curve shows no buffer capacity (Figure 2c). Indeed, pyrite strongly acidified the solution; when $\left[\mathrm{Eq} \mathrm{H} \mathrm{H}^{+}\right]=0$, the $\mathrm{pH}$ value was 4.65 . According to the literature, pyrite dissolution in an oxidizing environment occurs in two steps: (1) oxidation of sulfides (Equation (1)), and (2) oxidation of ferrous ion to ferric iron (Equation (2)), which is kinetically limiting $[45,47]$. These reactions are self-catalyzed by the direct oxidation of pyrite by ferric iron (Equation (3)) for $\mathrm{pH}<3.5$. This is the predominant reaction in the AMD process. It is this reaction that strongly acidifies the solution through the large production of protons [48].

$$
\begin{gathered}
\mathrm{FeS}_{2}+7 / 2 \mathrm{O}_{2}+\mathrm{H}_{2} \mathrm{O} \rightarrow \mathrm{Fe}^{2+}+2 \mathrm{SO}_{4}^{2-}+2 \mathrm{H}^{+} . \\
\mathrm{Fe}^{2+}+1 / 4 \mathrm{O}_{2}+\mathrm{H}^{+} \rightarrow \mathrm{Fe}^{3+}+1 / 2 \mathrm{H}_{2} \mathrm{O} . \\
\mathrm{FeS}_{2}+14 \mathrm{Fe}^{3+}+8 \mathrm{H}_{2} \mathrm{O} \rightarrow 15 \mathrm{Fe}^{2+}+2 \mathrm{SO}_{4}{ }^{2-}+16 \mathrm{H}^{+} .
\end{gathered}
$$

The difference in value between modeled and measured pe demonstrates the oxidative impact of pyrite dissolution, mainly through Equation (1), which was represented by the geochemical model [46].

The curve for calcite/pyrite $/ \mathrm{SiO}_{2}$ shows a $\mathrm{pH}$ evolution similar to that for calcite $/ \mathrm{SiO}_{2}$ (Figure 2a,e). The $\mathrm{pH}$ level, stable at approximately $\mathrm{pH}=6$, can be associated with the buffer capacity of calcite. The same content of acid $(0.55 \mathrm{~mol} / \mathrm{L})$ was required to complete the calcite dissolution and decrease the $\mathrm{pH}$. The potential redox curve is similar to that of pyrite $/ \mathrm{SiO}_{2}$ in terms of shape (Figure $2 \mathrm{~d}, \mathrm{f}$ ). However, there is a shift of the step change from $\mathrm{pH} \approx 2$ for pyrite $/ \mathrm{SiO}_{2}$ only to $\mathrm{pH} \approx 8$ for calcite/pyrite/ $\mathrm{SiO}_{2}$ (Figure $2 \mathrm{f}$ ). Such a shift supports the hypothesis on the impact of calcite on pyrite dissolution and the related effects on $\mathrm{pH}$ and pe. The model displays this impact in more detail (Figure 3). Indeed, the pyrite phase is expected to dissolve completely at $\mathrm{pH}=7$ in the calcite/pyrite $/ \mathrm{SiO}_{2}$ mineral assemblage, whereas the pyrite phase is expected to dissolve completely only at $\mathrm{pH}=2$ in the pyrite $/ \mathrm{SiO}_{2}$ assemblage. Furthermore, even in contact with pure water, pyrite dissolves less when it is the sole mineral than when it is combined with calcite (Figure 3). The parameters related to geochemical modeling are listed in Table 2 and were optimized by fitting experimental data, as explained in Section 2.

\subsection{Solubility and Speciation of Elements}

Below, we investigate the elemental release of calcium (provided by the dissolution of calcite), as well as iron and sulfur (provided by the dissolution of pyrite). The characterization and modeling of their release help in identifying the phases that dissolve and potentially form, as well as the geochemical processes involved in the evolution of the calcite $/ \mathrm{SiO}_{2}$, pyrite $/ \mathrm{SiO}_{2}$, and calcite/pyrite $/ \mathrm{SiO}_{2}$ assemblages. 


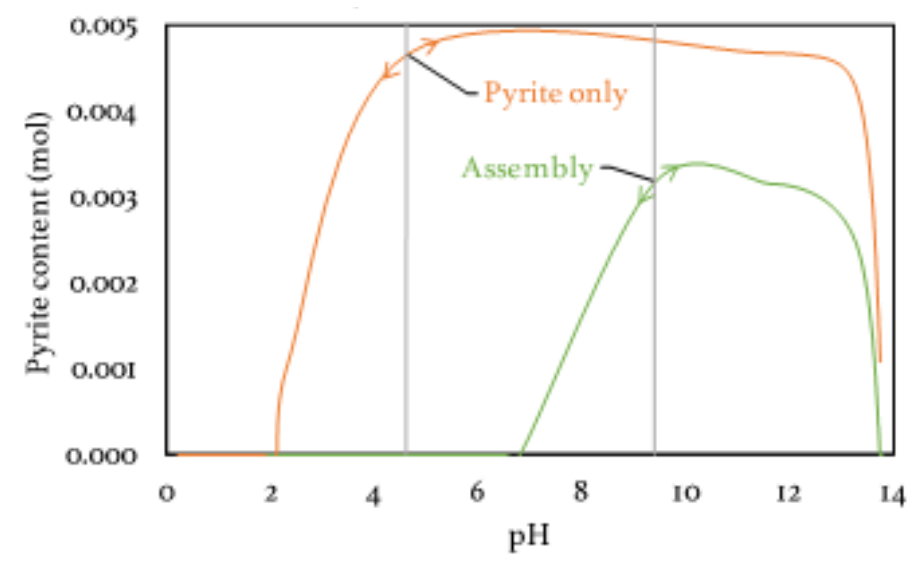

Figure 3. Impact of calcite on pyrite dissolution; arrows indicate the direction of addition or depletion of protons; the vertical line indicates the point of equilibrium with pure water (natural $\mathrm{pH}$ ).

Table 2. Mineral and gas contents of three synthetic matrices: (1) calcite $/ \mathrm{SiO}_{2}$, (2) pyrite $/ \mathrm{SiO}_{2}$, and (3) calcite/pyrite/SiO ; other tabulated minerals are expected to form and take part in transitional states.

\begin{tabular}{|c|c|c|c|c|c|}
\hline \multirow[t]{2}{*}{ Phases } & \multirow[t]{2}{*}{ Dissolution Equation } & \multirow{2}{*}{$\begin{array}{c}\text { Solubility } \\
\text { Constant } \\
\operatorname{logK}\end{array}$} & \multicolumn{3}{|c|}{$\begin{array}{l}\text { Initial Content (mol/L)/ } \\
\text { Partial Pressure (atm) }\end{array}$} \\
\hline & & & (1) & (2) & (3) \\
\hline \multicolumn{6}{|c|}{ Mineral Phases } \\
\hline Calcite (DO) & $\mathrm{CaCO}_{3}+\mathrm{H}^{+}=\mathrm{Ca}^{2+}+\mathrm{HCO}_{3}^{-}$ & 1.84 & 0.285 & - & 0.285 \\
\hline Foshagite & $\mathrm{Ca}_{4} \mathrm{Si}_{3} \mathrm{O}_{9}(\mathrm{OH})_{2}: 0.5 \mathrm{H}_{2} \mathrm{O}+\mathrm{H}^{+}=3 \mathrm{SiO}_{2}+4 \mathrm{Ca}^{2+}+5.5 \mathrm{H}_{2} \mathrm{O}$ & 65.9 & 0 & - & 0 \\
\hline Pyrite (DO) & $\mathrm{FeS}_{2}+\mathrm{H}_{2} \mathrm{O}=0.25 \mathrm{H}^{+}+0.25 \mathrm{SO}_{4}{ }^{2-}+\mathrm{Fe}^{2+}+1.75 \mathrm{HS}^{-}$ & -24.7 & - & 0.0047 & 0.0032 \\
\hline Quartz (DO) & $\mathrm{SiO}_{2}=\mathrm{SiO}_{2}$ & -4.00 & 1.165 & 0.0165 & 0.0115 \\
\hline Gypsum & $\mathrm{CaSO}_{4}: 2 \mathrm{H}_{2} \mathrm{O}=\mathrm{Ca}^{2+}+\mathrm{SO}_{4}{ }^{2-}+2 \mathrm{H}_{2} \mathrm{O}$ & -4.48 & - & - & 0 \\
\hline $\mathrm{Fe}(\mathrm{OH})_{2}$ & $\mathrm{Fe}(\mathrm{OH})_{2}+2 \mathrm{H}^{+}=\mathrm{Fe}^{2+}+2 \mathrm{H}_{2} \mathrm{O}$ & 13.9 & - & 0 & 0 \\
\hline $\mathrm{Fe}(\mathrm{OH})_{3}$ & $\mathrm{Fe}(\mathrm{OH})_{3}+3 \mathrm{H}^{+}=\mathrm{Fe}^{3+}+3 \mathrm{H}_{2} \mathrm{O}$ & 5.66 & - & 0 & 0 \\
\hline \multicolumn{6}{|c|}{ Gas Phases } \\
\hline $\operatorname{Ar}(\mathrm{g})$ & $\mathrm{Ar}=\mathrm{Ar}$ & -2.86 & & 0.0934 & \\
\hline $\mathrm{CO}_{2}(\mathrm{~g})$ & $\mathrm{CO}_{2}+\mathrm{H}_{2} \mathrm{O}=\mathrm{H}^{+}+\mathrm{HCO}_{3}^{-}$ & -7.81 & & 0.00037 & \\
\hline $\mathrm{N}_{2}(\mathrm{~g})$ & $\mathrm{N}_{2}=\mathrm{N}_{2}$ & -3.19 & & 0.781 & \\
\hline $\mathrm{O}_{2}(\mathrm{~g})$ & $\mathrm{NO}_{2}+0.5 \mathrm{H}_{2} \mathrm{O}+0.25 \mathrm{O}_{2}=\mathrm{H}^{+}+\mathrm{NO}_{3}^{-}$ & 8.37 & & 0.00207 & \\
\hline
\end{tabular}

DO, Dissolve only: do not allow mineral to precipitate in model.

\subsubsection{Calcium}

The curve of soluble calcium (Figure 4a) indicates maximum content at an acidic $\mathrm{pH}$. Approximately $0.29 \mathrm{~mol} / \mathrm{L}$ of calcium was released at $\mathrm{pH}<6$, representing $97 \%$ of the initial calcium introduced with the calcite (Table 1). This finding confirms the hypothesis that the buffer capacity of the solid phase of calcite results from calcite dissolution. The fast kinetics of calcite dissolution explains the significant content of calcium release [37,49]. Figure $4 \mathrm{~b}$ shows the modeled calcium speciation as a function of $\mathrm{pH}$. Soluble calcium was mainly in the form of $\mathrm{Ca}^{2+}$ (approximately 60\%) and $\mathrm{CaNO}^{+}$(approximately $40 \%$ ), due to the addition of $\mathrm{HNO} 3$ for acidification of the solution. In the basic area, calcium was scarcely released, to an extent of less than $1 \%$ (Table 1 ).

There are few differences between calcite $/ \mathrm{SiO}_{2}$ and calcite/pyrite $/ \mathrm{SiO}_{2}$ regarding calcium release and speciation (Figure $4 \mathrm{c}, \mathrm{d}$ ). At an acidic $\mathrm{pH}, 99 \%$ of the calcium introduced initially was solubilized (see Table 2 for the assemblage). However, the gypsum phase $\left(\mathrm{CaSO}_{4}\right)$ precipitated at $4<\mathrm{pH}<8$ without any significant effect on calcium release, given the small amount of precipitated $\mathrm{CaSO}_{4}$. 

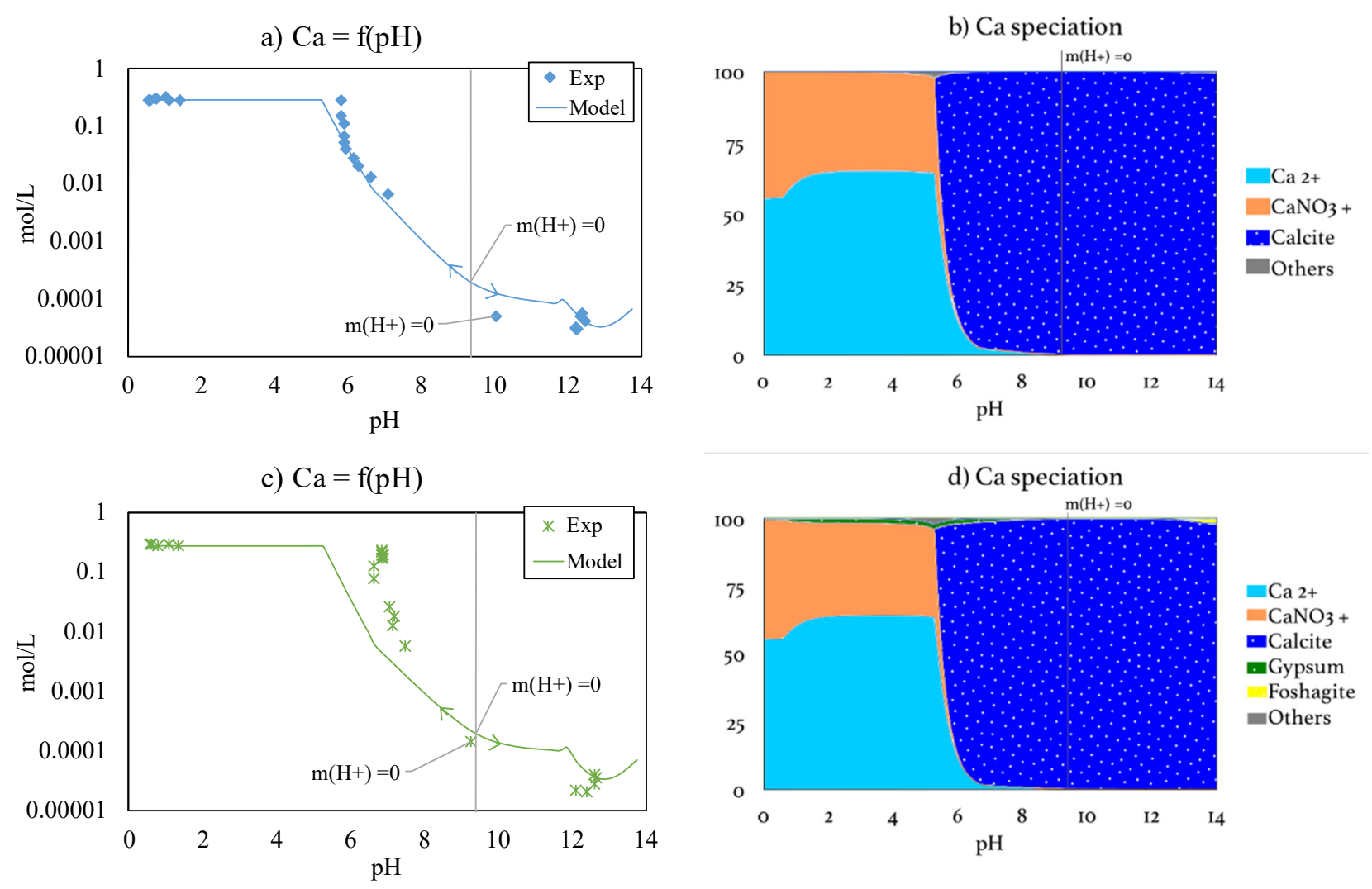

Figure 4. Total experimental soluble content and modeled speciation of calcium as a function of $\mathrm{pH}$ : $(\mathbf{a}, \mathbf{b}) \mathrm{calcite} / \mathrm{SiO} \mathrm{O}_{2}$ and $(\mathbf{c}, \mathbf{d})$ calcite/pyrite $/ \mathrm{SiO}_{2}$. Arrows indicate the direction of addition or depletion of protons; the vertical line indicates the point of equilibrium with pure water (natural $\mathrm{pH}$ ).

\subsubsection{Iron}

Figure 5 shows the soluble content and modeled speciation curves of iron with $\mathrm{pH}$ for pyrite $/ \mathrm{SiO}_{2}$ and calcite/pyrite $/ \mathrm{SiO}_{2}$. Between the two, the variations in solubility with $\mathrm{pH}$ have similar trends. However, the modeled speciation is quite different. For pyrite $/ \mathrm{SiO}_{2}$, iron speciation represents the reaction sequence described previously (Equations (1)-(3)). Indeed, iron in solution was mainly in the form of ferrous iron. This mechanism demonstrates the importance of $\mathrm{O}_{2}(\mathrm{~g})$ and the catalytic oxidant impact of ferric iron [9,50]. Once the pyrite phase completely dissolved, iron in the solution was mainly in the form of ferric iron. On the other hand, speciation of iron for the calcite/pyrite $/ \mathrm{SiO}_{2}$ assemblage was different. Indeed, ferrous iron no longer appeared. The pyrite phase completely dissolved at $\mathrm{pH}<7$ with the precipitation of iron hydroxide mineral $(\mathrm{Fe}(\mathrm{OH}) 3)$. According to the literature, when $\mathrm{pH}>3.5$, oxidation of ferric and ferrous iron is important and iron hydroxide will precipitate, as follows $[9,41,47]$ :

$$
\mathrm{Fe}^{3+}+3 \mathrm{H}_{2} \mathrm{O} \leftrightharpoons \mathrm{Fe}(\mathrm{OH})_{3}+3 \mathrm{H}^{+} .
$$

The model confirmed the impact of the carbonate phase on sulfur dissolution. Thus, when a carbonate buffers the solution up to $\mathrm{pH} 3.5$, the ferric iron does not act as an oxidant. Meanwhile, the precipitation equation of $\mathrm{Fe}(\mathrm{OH})_{3}$ (Equation (4)) acidified the solution, but the calcite dissolution compensated for it, leading to stabilization of $\mathrm{pH}$ over 3.5 [39]. This also explains the impact on redox potential; the step change shifted and was softer because the ferric iron no longer played its oxidation role.

Iron was released very little under basic conditions, less than $1 \%$ in both studies (Table 1). Conversely, in the acidic area, iron was released in solution at a rate of $45 \%$ for pyrite $/ \mathrm{SiO}_{2}$ and $25 \%$ for calcite/pyrite $/ \mathrm{SiO}_{2}$. These results support the chemical mechanisms previously outlined. Indeed, in a carbonaceous environment, $\mathrm{Fe}(\mathrm{OH})_{3}$ precipitation (Equation (4)) decreased the iron content in solution. 

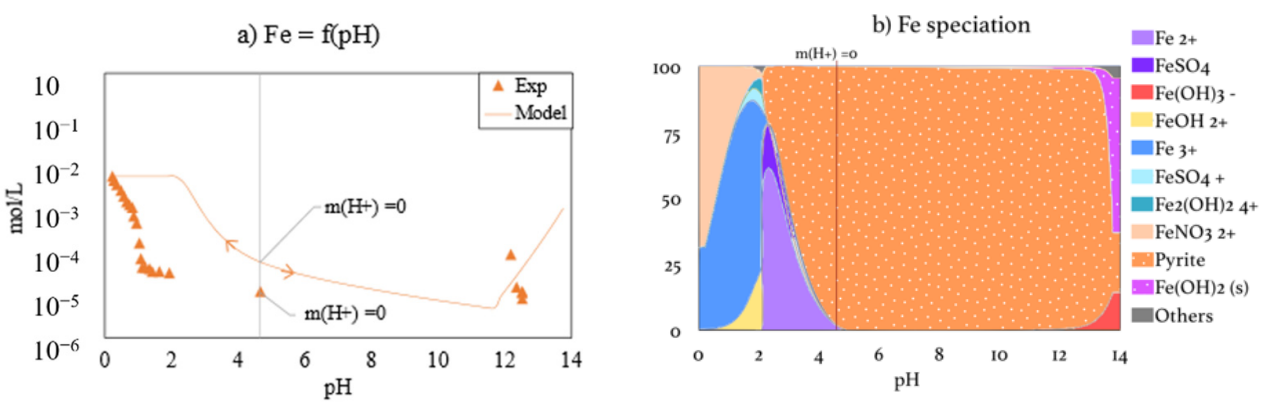

c) $\mathrm{Fe}=\mathrm{f}(\mathrm{pH})$
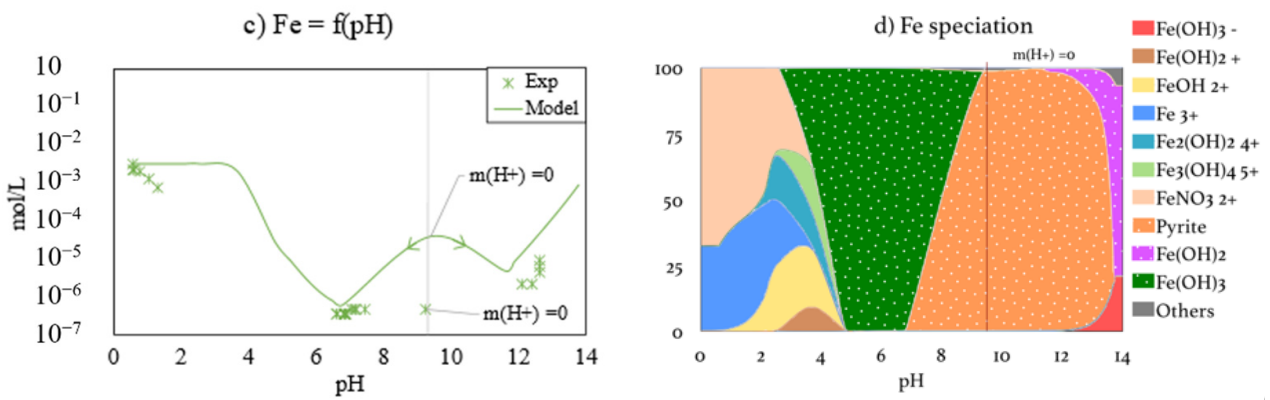

Figure 5. Total experimental soluble content and modeled speciation of iron as a function of $\mathrm{pH}$ : $(\mathbf{a}, \mathbf{b})$ pyrite $/ \mathrm{SiO}_{2}$ and $(\mathbf{c}, \mathbf{d})$ calcite/pyrite $/ \mathrm{SiO}_{2}$. Arrows indicate the direction of addition or depletion of protons; the vertical line indicates the point of equilibrium with pure water (natural $\mathrm{pH}$ ).

\subsubsection{Sulfur}

The solubility and speciation curves of sulfur are different between pyrite $/ \mathrm{SiO}_{2}$ and calcite/pyrite $/ \mathrm{SiO}_{2}$ (Figure 6). In both cases, sulfur was mainly in the form of $\mathrm{SO}_{4}{ }^{2-}$, then $\mathrm{HSO}_{4}{ }^{3-}$ when $\mathrm{pH}<3$. According to the literature, this results from the addition of protons and the acid-base properties of sulfur [41]. Moreover, the model supports the results from experiments with varying anion concentrations $\left(\mathrm{SO}_{4}{ }^{2-}\right)$ [41]. For the assemblage, the precipitation of gypsum considerably reduced the release of sulfur in the acidic area, despite the complete dissolution of pyrite. Similar to iron, these results highlight pyrite dissolution at alkaline $\mathrm{pH}$ values more than calcite dissolution, which buffers the solution.
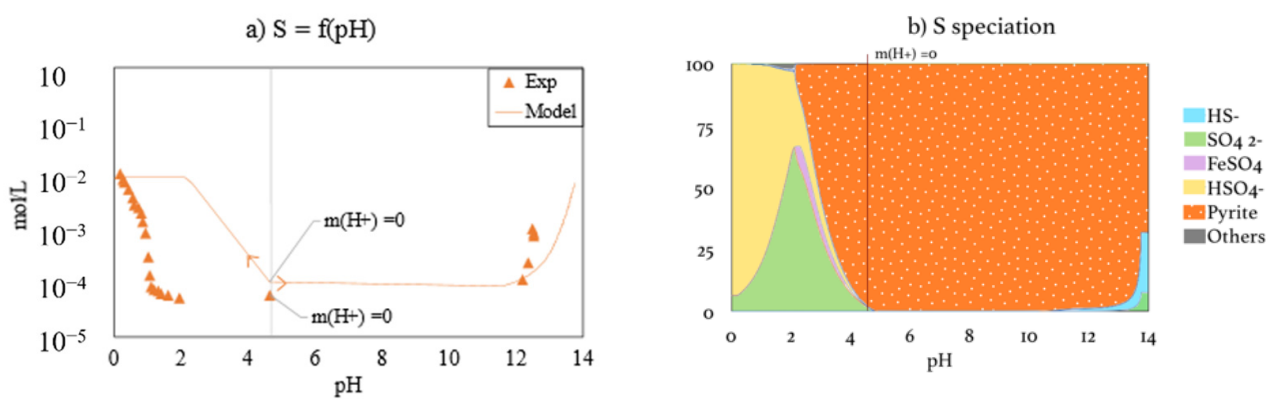

c) $\mathrm{S}=\mathrm{f}(\mathrm{pH})$
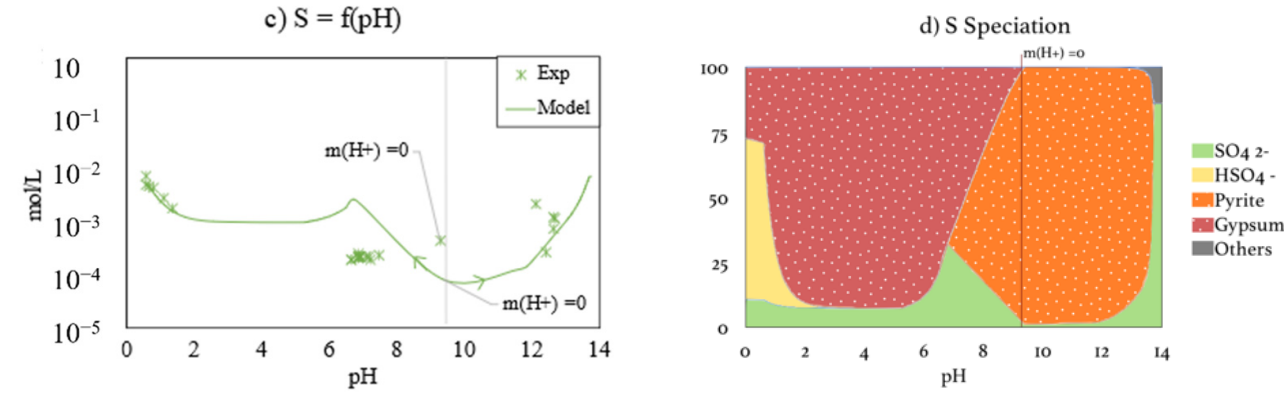

Figure 6. Total experimental soluble content and modeled speciation of sulfur as a function of $\mathrm{pH}$ : $(\mathbf{a}, \mathbf{b})$ pyrite $/ \mathrm{SiO}_{2}$ and $(\mathbf{c}, \mathbf{d})$ calcite/pyrite $/ \mathrm{SiO}_{2}$. Arrows indicate the direction of addition or depletion of protons; the vertical line indicates the point of equilibrium with pure water (natural $\mathrm{pH}$ ). 
In the basic area, the leaching of sulfur was significant (Table 1 ) with $6 \%$ for pyrite $/ \mathrm{SiO}_{2}$ versus $11 \%$ for calcite/pyrite $/ \mathrm{SiO}_{2}$. No sulfur-containing mineral precipitated under these $\mathrm{pH}$ conditions (Figure $6 \mathrm{~b}, \mathrm{~d}$ ). In the acidic area, sulfur was also released as follows: $52 \%$ for pyrite $/ \mathrm{SiO}_{2}$ and $37 \%$ for calcite/pyrite $/ \mathrm{SiO}_{2}$. Again, these results support the mechanisms previously presented and agree with the literature [41].

\section{Discussion}

Our results clearly show that carbonate phases buffer the solution and modify pyrite dissolution, without preventing it. The mechanism of neutralization of sulfuric acid by calcite may be modeled by considering the following equation, as suggested by Lapakko et al. [10]:

$$
2 \mathrm{CaCO}_{3}+\mathrm{H}_{2} \mathrm{SO}_{4} \rightarrow 2 \mathrm{Ca}^{2+}+2 \mathrm{HCO}_{3}{ }^{-}+\mathrm{SO}_{4}{ }^{2-} \text {. }
$$

This mechanism was particularly well represented by the model and the modeled results of sulfur speciation (Figure 6d). Indeed, unlike the pyrite $/ \mathrm{SiO}_{2}$ assemblage, in the calcite/pyrite $/ \mathrm{SiO}_{2}$ assemblage, $\mathrm{HSO}_{4}{ }^{-}$did not appear in solution before $\mathrm{pH}<2$, at the beginning of gypsum dissolution. At $\mathrm{pH}>2, \mathrm{HSO}_{4}{ }^{-}$was transformed by the buffering capacity of the carbonate phase into $\mathrm{SO}_{4}{ }^{2-}$. Modeling and speciation provided an important understanding of the mechanisms involved in the geochemical evolution of the assemblage of pyrite and calcite.

Therefore, the proposed geochemical model in this paper satisfactorily reports the complexity and interdependence between the dissolution of mineral phases during ANCBNC titration. Figure 7 presents these complex and essential aspects of pyrite dissolution dependent on acid-base conditions and, thus, the presence of calcite. Whatever the acidbase conditions, oxygen allows pyrite dissolution to begin. This results in the production of ferrous iron and acid (Equation (1)). The ferrous iron is then oxidized to ferric iron through oxygen and a proton (Equation (2)). Depending on the environmental conditions, the reactions that follow are different. In very acidic conditions $(\mathrm{pH}<3.5)$, ferric iron and water allow for pyrite dissolution. Ferrous iron and many protons are produced (Equation (3)). It is this quantity of protons that strongly acidifies the leachate and causes acid mine drainage. Pyrite dissolution can be very important, because, with the initial oxidation, ferric iron is auto-catalyzed (Equation (3)). In more basic conditions ( $\mathrm{pH}>3.5$ ), iron hydroxide precipitation $\left(\mathrm{Fe}(\mathrm{OH})_{3}\right)$ dissolves the pyrite phase, without $\mathrm{Fe}^{2+} / \mathrm{Fe}^{3+}$ saturation. However, because Equations (1) and (3) produce protons and $\mathrm{SO}_{4}{ }^{2-}$, a mineral phase with high buffer capacity is required to maintain $\mathrm{pH}>3.5$, causing the contaminated neutral drainage. The carbonate dissolution provides $\mathrm{CO}_{3}{ }^{2-}$, which can stabilize the $\mathrm{pH}$ above 3.5.

The conclusions of this study are based on experimental data that were obtained for specific proportions of calcite and pyrite. However, depending on the mining waste, the contents may vary. The geochemical model employed to fit our experimental data was used to predict pyrite dissolution for several scenarios. Figure 8 shows pyrite dissolution as a function of $\mathrm{pH}$ for different values of the ratio of calcite and pyrite contents $(\mathrm{mol} / \mathrm{mol})$ : $1 / 100,1 / 10,1,10,100$, and 1000 . Note that our experimental results were obtained for a ratio of $88(\mathrm{~mol} / \mathrm{mol})$. Very low calcite content had little influence on pyrite dissolution and $\mathrm{pH}$ in pure water (see crosses in Figure 8 corresponding to $\mathrm{m}\left(\mathrm{H}^{+}\right)=0$ ). As soon as $1 / 10$ calcite was introduced, the $\mathrm{pH}$ in pure water reached a value of 9.3. The calcite phase took the lead. When the calcite content increased, the dissolution of pyrite was complete at increasingly alkaline $\mathrm{pH}: \mathrm{pH}=2$ for $1 / 100$ of the nominal calcite content versus $\mathrm{pH}=3$ for the nominal content (calcite/pyrite $=1$ ). For ratios greater than 10, similar impacts of calcite on pyrite dissolution were observed, with complete dissolution at $\mathrm{pH} \approx 6.5$. Sufficient calcite content is required to buffer the solution, as pyrite dissolution produces considerable acidity (Figure 7). 


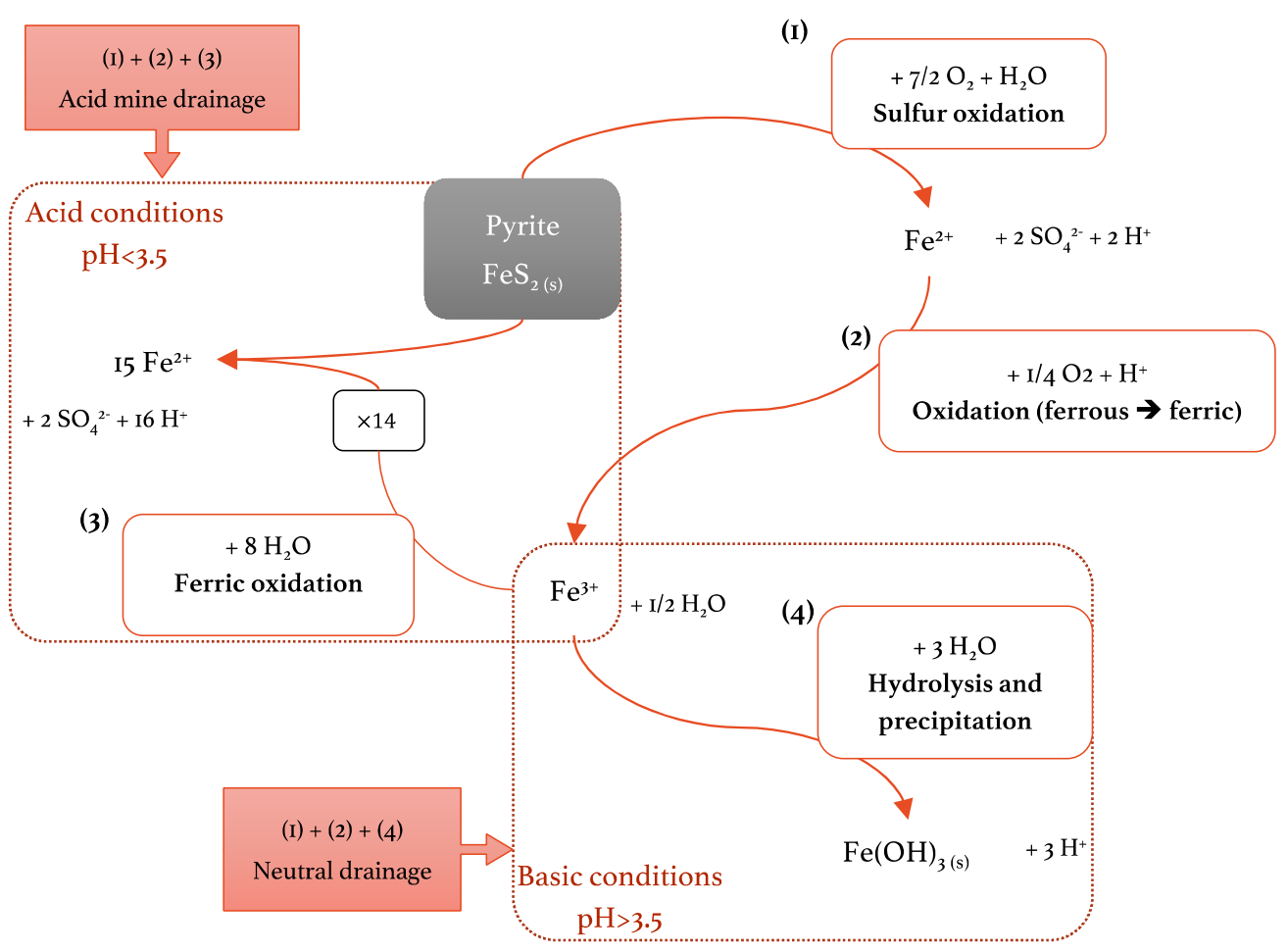

Figure 7. Processes of pyrite dissolution as a function of $\mathrm{pH}[1,9,22,39,40,51,52]$.

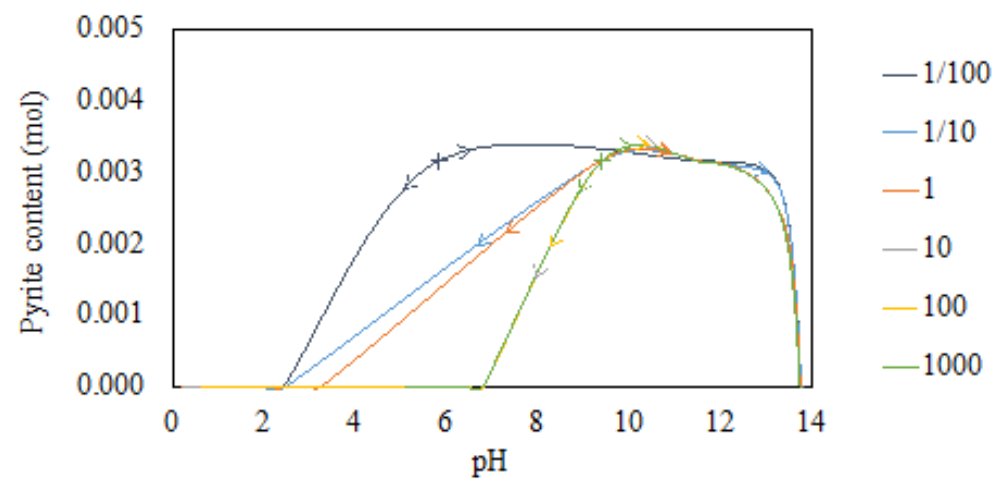

Figure 8. Models of pyrite dissolution as a function of calcite content (calcite/pyrite ratio in $\mathrm{mol} / \mathrm{mol}$ ) in calcite/pyrite $/ \mathrm{SiO}_{2}$ assemblage. Arrows indicate the direction of addition or depletion of protons; crosses indicate the point of equilibrium with pure water (natural $\mathrm{pH}$ ).

\section{Conclusions}

This study investigated the potential of ANC-BNC titration combined with geochemical modeling for the characterization of mining waste in terms of buffer capacity and element release and identification of the main parent mechanisms. We used the European standard NF EN 14429 [31] to perform ANC-BNC titrations on three synthetic mineral assemblages representing common mining wastes (for the two last mineral assemblages): calcite $/ \mathrm{SiO}_{2}$, pyrite $/ \mathrm{SiO}_{2}$, and calcite/pyrite $/ \mathrm{SiO}_{2}$. ANC-BNC titrations were combined with geochemical modeling to interpret $\mathrm{pH}$, redox potential, and element release evolution as a function of the added amounts of acid or base. Geochemical modeling was used to relate the main buffer zones and releases to mineral precipitation or dissolution.

The application of the proposed approach (ANC-BNC combined with geochemical modeling) proved efficient to (i) characterize the three synthetic matrices by approaching their real composition and (ii) identify the main processes involved in element release and the production of AMD and CND. The acid-base neutralization capacity test introduced differences among the three matrices (calcite $/ \mathrm{SiO}_{2}$, pyrite $/ \mathrm{SiO}_{2}$, and calcite/pyrite $/ \mathrm{SiO}_{2}$ ), 
which were supported and developed by the proposed geochemical model. The modeling approach very satisfactorily simulated our experimental results $(\mathrm{pH}$ and element release data) and provided results in line with previous studies, whereas the modeling of pe trends seemed trickier. The geochemical model explained the differences in the dissolution of pyrite depending on the presence of calcite $[1,38]$. Separately, pyrite and calcite had an equilibrium $\mathrm{pH}$ in pure water of $\sim 4.5$ and $\sim 9.0$, respectively. The addition of base did not affect the pyrite and calcite phases. The addition of acid to solution resulted in phase dissolution. However, the synthetic matrices behaved differently with acid; the addition of acid resulted in the catalysis of pyrite dissolution by the neutralizing capacity of the calcite phase. The calcite dissolution provided $\mathrm{CO}_{3}{ }^{-}$ions, which allowed for stabilization of the $\mathrm{pH}$ value in the basic area. At these high $\mathrm{pH}$ values, $\mathrm{Fe}^{3+}$ precipitated as iron hydroxide, which permitted pyrite dissolution without acidification of the solution. These chemical mechanisms, involved in both AMD and CND, emphasize the crucial role of the carbonate phase in pyrite and sulfide dissolution, especially the speciation of released elements. Despite the carbonate buffer capacity, the dissolution of pyrite and other potential trace element-bearing phases is not prohibited [22]. Thus, even if the leachate is not acidic, pyrite may dissolve, thereby releasing sorbed heavy metals. Consequently, the addition of calcite may not be sufficient to entirely mitigate the environmental hazard [17]. This analytical approach of associating experimentation and modeling allowed for a quite accurate understanding of the various geochemical mechanisms. The approach assumes some prospects and adaptations for other matrices.

This study investigated the geochemical processes of pure phases. However, real matrices may behave differently. First of all, the phases may be much more complex from a thermodynamic point of view, with additional complex mechanisms (precipitation and dissolution kinetics, passivation of calcite, coating of mineral surfaces due to precipitation, etc.) [53]. In addition, biological processes were not considered, and these are known to impact AMD, with Fe-oxidizing bacteria involved in the generation of ferric iron and the acceleration of pyrite dissolution [54]. Additional tests should be conducted with different types of strains to investigate the influence of bacteria on AMD and CND processes. The question of toxicity and the fate of bacterial communities in these peculiar environments should be addressed. The proposed study offers a general frame for understanding the main geochemical processes responsible for AMD and highlights the need to account for the specifics of each real matrix, its compositions (pyrite-calcite ratio), and its related environment. Ongoing research will focus on applying the proposed method to complex matrices such as real mining waste or urban sediments.

Author Contributions: Conceptualization, C.D. (Clémentine Drapeau), L.L., and C.D. (Cécile Delolme); methodology, C.D. (Clémentine Drapeau), L.L., and C.D. (Cécile Delolme); software, C.D. (Clémentine Drapeau) and C.V. with the help of L.L., C.D. (Cécile Delolme), D.B., M.E., and T.B.; validation, C.D. (Clémentine Drapeau), L.L., and C.D. (Cécile Delolme); resources, C.D. (Cécile Delolme) and L.L.; data curation, C.V. and C.D. (Clémentine Drapeau); writing-original draft preparation, C.D. (Clémentine Drapeau) with the help of L.L. and C.D. (Cécile Delolme); writing-review and editing, all authors. All authors read and agreed to the published version of the manuscript.

Funding: This research received no external funding.

Data Availability Statement: Not applicable.

Acknowledgments: The authors would like to thank Nathalie Dumont and David Lebouil (Laboratoire Déchets Eau Environnement Pollutions, DEEP) and Myriam Hammada (Laboratories d'Ecologie des Hydrosystèmes Naturels et Anthropisés, LEHNA) for technical assistance and analytical analyses. The authors are grateful to the field observatory for urban water management (OTHU) and CNRS EC2CO for their logistical and financial support.

Conflicts of Interest: The authors declare no conflict of interest. 


\section{References}

1. Argane, R.; El Adnani, M.; Benzaazoua, M.; Bouzahzah, H.; Khalil, A.; Hakkou, R.; Taha, Y. Geochemical Behavior and Environmental Risks Related to the Use of Abandoned Base-Metal Tailings as Construction Material in the Upper-Moulouya District, Morocco. Environ. Sci. Pollut. Res. 2016, 23, 598-611. [CrossRef] [PubMed]

2. Hakkou, R.; Benzaazoua, M.; Bussière, B. Acid Mine Drainage at the Abandoned Kettara Mine (Morocco): 2. Mine Waste Geochemical Behavior. Mine Water Environ. 2008, 27, 160-170. [CrossRef]

3. Wolkersdorfer, C.; Bowell, R. Contemporary Reviews of Mine Water Studies in Europe. Mine Water Environ. $2004,23,161$. [CrossRef]

4. Azam, S.; Li, Q. Tailings Dam Failures: A Review of the Last One Hundred Years. Geotech. News 2010, $28,50-54$.

5. Khalil, A.; Hanich, L.; Bannari, A.; Zouhri, L.; Pourret, O.; Hakkou, R. Assessment of Soil Contamination around an Abandoned Mine in a Semi-Arid Environment Using Geochemistry and Geostatistics: Pre-Work of Geochemical Process Modeling with Numerical Models. J. Geochem. Explor. 2013, 125, 117-129. [CrossRef]

6. Othmani, M.A.; Souissi, F.; Bouzahzah, H.; Bussière, B.; Da Silva, E.F.; Benzaazoua, M. The Flotation Tailings of the Former $\mathrm{Pb}-\mathrm{Zn}$ Mine of Touiref (NW Tunisia): Mineralogy, Mine Drainage Prediction, Base-Metal Speciation Assessment and Geochemical Modeling. Environ. Sci. Pollut. Res. 2015, 22, 2877-2890. [CrossRef]

7. Yilmaz, E. Advances in Reducing Large Volumes of Environmentally Harmful Mine Waste Rocks and Tailings. Gospod. Surowcami Miner. 2011, 27, 89-112.

8. Morin, K.A.; Hutt, N.M. Environmental Geochemistry of Minesite Drainage: Practical Theory and Case Studies, Digital Edition; MDAG Publishing: Surrey, BC, Canada, 2001; ISBN 0-9682039-1-4.

9. Singer, P.C.; Stumm, W. Acidic Mine Drainage: The Rate-Determining Step. Science 1970, 167, 1121-1123. [CrossRef] [PubMed]

10. Lapakko, K.A.; Antonson, D.A.; Wagner, J.R. Mixing of Limestone with Finely-Crushed Acid Producing Rock. In Proceedings of the Fourth International Conference on Acid Rock Drainage, Vancouver, BC, Canada, 31 May-6 June 1997; pp. 1345-1360.

11. Plante, B.; Benzaazoua, M.; Bussière, B. Kinetic Testing and Sorption Studies by Modified Weathering Cells to Characterize the Potential to Generate Contaminated Neutral Drainage. Mine Water Environ. 2011, 30, 22-37. [CrossRef]

12. Bussiere, B. Colloquium 2004: Hydrogeotechnical Properties of Hard Rock Tailings from Metal Mines and Emerging Geoenvironmental Disposal Approaches. Can. Geotech. J. 2007, 44, 1019-1052. [CrossRef]

13. Heikkinen, P.M.; Räisänen, M.L.; Johnson, R.H. Geochemical Characterisation of Seepage and Drainage Water Quality from Two Sulphide Mine Tailings Impoundments: Acid Mine Drainage versus Neutral Mine Drainage. Mine Water Environ. 2009, 28 , 30-49. [CrossRef]

14. Benzaazoua, M.; Bussière, B.; Dagenais, A.-M.; Archambault, M. Kinetic Tests Comparison and Interpretation for Prediction of the Joutel Tailings Acid Generation Potential. Environ. Geol. 2004, 46, 1086-1101. [CrossRef]

15. Shu, W.S.; Ye, Z.H.; Lan, C.Y.; Zhang, Z.Q.; Wong, M.H. Acidification of Lead/Zinc Mine Tailings and Its Effect on Heavy Metal Mobility. Environ. Int. 2001, 26, 389-394. [CrossRef]

16. Benvenuti, M.; Mascaro, I.; Corsini, F.; Lattanzi, P.; Parrini, P.; Tanelli, G. Mine Waste Dumps and Heavy Metal Pollution in Abandoned Mining District of Boccheggiano (Southern Tuscany, Italy). Environ. Geol. 1997, 30, 238-243. [CrossRef]

17. Dold, B. Evolution of Acid Mine Drainage Formation in Sulphidic Mine Tailings. Minerals 2014, 4, 621-641. [CrossRef]

18. Abraitis, P.K.; Pattrick, R.A.D.; Vaughan, D.J. Variations in the Compositional, Textural and Electrical Properties of Natural Pyrite: A Review. Int. J. Miner. Process. 2004, 74, 41-59. [CrossRef]

19. Engelsen, C.J.; van der Sloot, H.A.; Wibetoe, G.; Petkovic, G.; Stoltenberg-Hansson, E.; Lund, W. Release of Major Elements from Recycled Concrete Aggregates and Geochemical Modelling. Cem. Concr. Res. 2009, 39, 446-459. [CrossRef]

20. Peyronnard, O.; Blanc, D.; Benzaazoua, M.; Moszkowicz, P. Study of Mineralogy and Leaching Behavior of Stabilized/Solidified Sludge Using Differential Acid Neutralization Analysis: Part II: Use of Numerical Simulation as an Aid Tool for Cementitious Hydrates Identification. Cem. Concr. Res. 2009, 39, 501-509. [CrossRef]

21. Halim, C.E.; Short, S.A.; Scott, J.A.; Amal, R.; Low, G. Modelling the Leaching of Pb, Cd, As, and Cr from Cementitious Waste Using PHREEQC. J. Hazard. Mater. 2005, 125, 45-61. [CrossRef]

22. Pérez-López, R.; Castillo, J.; Quispe, D.; Nieto, J.M. Neutralization of Acid Mine Drainage Using the Final Product from $\mathrm{CO}_{2}$ Emissions Capture with Alkaline Paper Mill Waste. J. Hazard. Mater. 2010, 177, 762-772. [CrossRef]

23. Coussy, S.; Benzaazoua, M.; Blanc, D.; Moszkowicz, P.; Bussière, B. Arsenic Stability in Arsenopyrite-Rich Cemented Paste Backfills: A Leaching Test-Based Assessment. J. Hazard. Mater. 2011, 185, 1467-1476. [CrossRef] [PubMed]

24. Tiruta-Barna, L. Using PHREEQC for Modelling and Simulation of Dynamic Leaching Tests and Scenarios. J. Hazard. Mater. 2008, 157, 525-533. [CrossRef]

25. Simate, G.S.; Ndlovu, S. Acid Mine Drainage: Challenges and Opportunities. J. Environ. Chem. Eng. 2014, 2, 1785-1803. [CrossRef]

26. Glass, G.K.; Buenfeld, N.R. Differential Acid Neutralisation Analysis. Cem. Concr. Res. 1999, 29, 1681-1684. [CrossRef]

27. Peyronnard, O.; Benzaazoua, M.; Blanc, D.; Moszkowicz, P. Study of Mineralogy and Leaching Behavior of Stabilized/Solidified Sludge Using Differential Acid Neutralization Analysis. Part I: Experimental Study. Cem. Concr. Res. 2009, 39, 600-609. [CrossRef]

28. Kania, M.; Gautier, M.; Blanc, D.; Lupsea-Toader, M.; Merlot, L.; Quaresima, M.-C.; Gourdon, R. Leaching Behavior of Major and Trace Elements from Sludge Deposits of a French Vertical Flow Constructed Wetland. Sci. Total Environ. 2019, 649, 544-553. [CrossRef] [PubMed] 
29. Brahy, V.; Deckers, J.; Delvaux, B. Estimation of Soil Weathering Stage and Acid Neutralizing Capacity in a Toposequence Luvisol-Cambisol on Loess under Deciduous Forest in Belgium. Eur. J. Soil Sci. 2000, 51, 1-13. [CrossRef]

30. Wahlström, M.; Laine-Ylijoki, J.; Kaartinen, T. Acid Neutralization Capacity of Waste-Specification of Requirement Stated in Landfill Regulations; Nordic Council of Ministers: Copenhagen, Denmark, 2009.

31. AFNOR. CEN/TS 14429 Characterization of Waste. Leaching Behavior Tests. Influence of PH on Leaching with Initial Acid/Base Addition; AFNOR: Paris, France, 2015.

32. Jamali, M.K.; Kazi, T.G.; Arain, M.B.; Afridi, H.I.; Jalbani, N.; Kandhro, G.A.; Shah, A.Q.; Baig, J.A. Speciation of Heavy Metals in Untreated Sewage Sludge by Using Microwave Assisted Sequential Extraction Procedure. J. Hazard. Mater. 2009, 163, $1157-1164$. [CrossRef]

33. Zuo, X.; Fu, D.; Li, H. Speciation Distribution and Mass Balance of Copper and Zinc in Urban Rain, Sediments, and Road Runoff. Environ. Sci. Pollut. Res. 2012, 19, 4042-4048. [CrossRef]

34. Parkhurst, D.L.; Appelo, C. User's Guide to PHREEQC (Version 2): A Computer Program for Speciation, Batch-Reaction, One-Dimensional Transport, and Inverse Geochemical Calculations; 1999.

35. Chatain, V.; Benzaazoua, M.; Cazalet, M.L.; Bouzahzah, H.; Delolme, C.; Gautier, M.; Blanc, D.; De Brauer, C. Mineralogical Study and Leaching Behavior of a Stabilized Harbor Sediment with Hydraulic Binder. Environ. Sci. Pollut. Res. 2013, 20, 51-59. [CrossRef] [PubMed]

36. Van der Sloot, H.A.; Van Zomeren, A.; Dijkstra, J.J.; Meeussen, J.C.L.; Comans, R.N.J.; Scharff, H. Prediction of the Leaching Behaviour of Waste Mixtures by Chemical Speciation Modelling Based on a Limited Set of Key Parameters. In Proceedings of the Tenth International Waste Management and Landfill Symposium, Sardinia, Italy; Report ECN-RX-05-164; Environmental Sanitary Engineering Centre: Cagliari, Italy; Energy Research Centre of the Netherlands: Petten, The Netherlands, 2005; Available online: www.ecn.nl (accessed on 28 February 2021).

37. Bouchelaghem, F. A Numerical and Analytical Study on Calcite Dissolution and Gypsum Precipitation. Appl. Math. Model. 2010, 34, 467-480. [CrossRef]

38. Chandra, A.P.; Gerson, A.R. The Mechanisms of Pyrite Oxidation and Leaching: A Fundamental Perspective. Surf. Sci. Rep. 2010, 65, 293-315. [CrossRef]

39. Evangelou, V.P.; Seta, A.K.; Holt, A. Potential Role of Bicarbonate during Pyrite Oxidation. Environ. Sci. Technol. 1998, 32, 2084-2091. [CrossRef]

40. Descostes, M.; Beaucaire, C.; Mercier, F.; Savoye, S.; Sow, J.; Zuddas, P. Effect of Carbonate Ions on Pyrite (FeS 2 ) Dissolution. Bull. Société Géologique Fr. 2002, 173, 265-270. [CrossRef]

41. Bonnissel-Gissinger, P.; Alnot, M.; Ehrhardt, J.-J.; Behra, P. Surface Oxidation of Pyrite as a Function of PH. Environ. Sci. Technol. 1998, 32, 2839-2845. [CrossRef]

42. Crundwell, F.K. The Mechanism of Dissolution of Minerals in Acidic and Alkaline Solutions: Part II Application of a New Theory to Silicates, Aluminosilicates and Quartz. Hydrometallurgy 2014, 149, 265-275. [CrossRef]

43. Morse, J.W.; Arvidson, R.S. The Dissolution Kinetics of Major Sedimentary Carbonate Minerals. Earth-Sci. Rev. 2002, 58, 51-84. [CrossRef]

44. Pokrovsky, O.S.; Golubev, S.V.; Schott, J.; Castillo, A. Calcite, Dolomite and Magnesite Dissolution Kinetics in Aqueous Solutions at Acid to Circumneutral PH, 25 to $150^{\circ} \mathrm{C}$ and 1 to 55 Atm PCO2: New Constraints on CO2 Sequestration in Sedimentary Basins. Chem. Geol. 2009, 265, 20-32. [CrossRef]

45. Stumm, W.; Morgan, J.J. Aquatic Chemistry: Chemical Equilibria and Rates in Natural Waters; John Wiley \& Sons: Hoboken, NJ, USA, 2012; Volume 126.

46. Sigg, L.; Stumm, W.; Behra, P. Chimie Des Milieux Aquatiques. Chim. Milieux Nat. 2000.

47. Garrels, R.M.; Thompson, M.E. Oxidation of Pyrite by Iron Sulfate Solutions. Am. J. Sci. 1960, 258, 57-67.

48. Williamson, M.A.; Rimstidt, J.D. The Kinetics and Electrochemical Rate-Determining Step of Aqueous Pyrite Oxidation. Geochim. Cosmochim. Acta 1994, 58, 5443-5454. [CrossRef]

49. Sjöberg, E.L.; Rickard, D.T. Temperature Dependence of Calcite Dissolution Kinetics between 1 and $62{ }^{\circ} \mathrm{C}$ at PH 2.7 to 8.4 in Aqueous Solutions. Geochim. Cosmochim. Acta 1984, 48, 485-493. [CrossRef]

50. Moses, C.O.; Herman, J.S. Pyrite Oxidation at Circumneutral PH. Geochim. Cosmochim. Acta 1991, 55, 471-482. [CrossRef]

51. Deutsch, W.J.; Siegel, R. Groundwater Geochemistry: Fundamentals and Applications to Contamination; CRC Press: Boca Raton, FL, USA, 1997.

52. Plante, B.; Benzaazoua, M.; Bussière, B. Predicting Geochemical Behaviour of Waste Rock with Low Acid Generating Potential Using Laboratory Kinetic Tests. Mine Water Environ. 2011, 30, 2-21. [CrossRef]

53. Lasaga, A.C.; Kirkpatrick, J. Kinetics of Geochemical Processes; Walter de Gruyter GmbH \& Co KG: Berlin, Germany, 2018 ; Volume 8.

54. Santelli, C.M.; Welch, S.A.; Westrich, H.R.; Banfield, J.F. The Effect of Fe-Oxidizing Bacteria on Fe-Silicate Mineral Dissolution. Exp. Theor. Geomicrobiol. 2001, 180, 99-115. [CrossRef] 